ETO: 821.511.141-31NÉMETH G.

821.163.41-31VELIKIĆ, D.

82.091

DOI: $10.19090 /$ hk.2020.4.41-53

\author{
FARAGÓ Kornélia \\ Újvidéki Egyetem, Bölcsészettudományi Kar \\ Magyar Nyelv és Irodalom Tanszék \\ Újvidék, Szerbia \\ kornelija.farago@ff.uns.ac.rs
}

\title{
PRODUKTÍV TÁVOLSÁGOK - NARRATÍV KOMMUNIKÁCIÓS MODELLEK
}

Németh Gábor: Egy mormota nyara - Dragan Velikić: Islednik

\section{Productive distances - Narrative communication models}

Gábor Németh: The Summer of a Marmot - Dragan Velikić: Investigator

\section{Produktivne razdaljine - narativni komunikacijski modeli \\ Németh Gábor: Leto jednog mrmota - Dragan Velikić: Islednik}

A tanulmány az emlékezeti szférában rejlő esztétikai potenciál előhívására alkalmas jelenkori narratív elképzelések iránt érdeklődik, és mindenekelőtt azt a kérdést teszi fel, hogyan működnek a valakihez beszélés és a valakiről való beszélés alakzatai, amikor az elbeszélő fiktív önkeresései és a családtörténeti viszonyok rejtett kiterjedései válnak az elbeszélés tárgyává. Milyen markánsabb dimenziói vannak annak a nyitott szerkezetnek, amely az esetleges kombinációk müködése folytán áll elő? Amennyiben Németh Gábor Egy mormota nyara vagy Dragan Velikić A nyomolvasó címü „helyszínkereső” regényét olvassuk, az is felmerül, hogy milyen megértési koncepciót dolgoz ki a mai regény a kulturális távolságokat, az idegenségtapasztalati témákat illetően, mit sajátít ki a szorongás és a félelem élményvilágából a maga számára, hogyan játszódik le a kiválasztás és az átalakítás kettős folyamata. Kulcsszavak: delokúciós valóság, idegenségpoétika, interlokúció, kommunikatív dimenzió, regény

Az emlékezeti szférában rejlő esztétikai potenciál előhívására alkalmas jelenkori szerkezeti elképzelések iránt érdeklődik a tanulmány, és mindenekelőtt azt a kérdést teszi fel, hogyan müködnek a valakihez beszélés és a valakiről való 
beszélés alakzatai, amikor az elbeszélö önkeresései és a családtörténeti viszonyok rejtett kiterjedései válnak a narráció tárgyává. Milyen markánsabb dimenziói vannak annak a szerkezetnek, amely az esetleges kombinációk müködése folytán áll elő? Amennyiben Németh Gábor Egy mormota nyara vagy éppen Dragan Velikić $A$ nyomolvasó címủ regényét olvassuk, az is felmerül, hogy mit sajátít ki a mai regény a jelenkori idegenségtapasztalati, távolságtapasztalati anyagokból, az intenzív érzések arzenáljából a maga számára, hogyan hat az elbeszélésalakítási szabadság a kiválasztás és az átalakítás kettős folyamatára. Milyen együttműködés jöhet létre az említett elbeszélési alakzatok között? Milyen formákra, tematikus mozzanatokra, előhívásokra és aktualizációs megoldásokra van szüksége az emlékezetnek, hogy „,regényes” módon bontakozhassék ki? Miként állítható elő a tényelbeszélés, illetőleg a tényorientált értelmezés fikciója az emlék narratív megközelítésében, s hogy milyen a külső hivatkozás, a történetileg beazonosítható mozzanat vagy az intertextus, a dokumentum rangja a privát létesemények közvetítésében?

Németh Gábor Egy mormota nyara címü regényét olvasva azt tapasztaljuk, hogy a valakihez beszélés, az implicit olvasónak szóló beszédmenet (a Másikhoz szólva, a Másik vonatkozásában írni) nagyban meghatározza a szövegszervezés módját. Már a szövegkezdet bevezeti a narratee alakzatát, az odaértett olvasóét, akivel ily módon az elbeszélő narratív kommunikációba léphet, a megszólított fényképének jelenléte (amely pontosítja, hogy kihez szól a beszéd) külön is jelzi, hogy nem a közvetlen beszédérintkezés fikciójáról van szó. Mindeközben az elbeszélő maga is mondatokat hall eltérő hangokon, és mint egy tollbamondás szövegét, mint egy idézeti anyagot használja, jegyzi le ezeket a belső-külső sugallatokat, a „saját” gondolataival elkeverve, olykor szinte szétválaszthatatlanul. Egyfajta szélességet az is elöállít, hogy az elbeszélő nagyon különböző személyek hangján hallja a lejegyzett (az önmagától eltávolított) mondatokat, „többnyire férfiak hangján, de előfordult már az is, hogy kisfiú beszélt, vagy fiatal lány" (Németh 2016, 10). Dragan Velikić regényében a fiú az anya hangját belülről visszahallva ért meg, mond ki bizonyos dolgokat, de az idegen hangok közvetítőjeként értett beszélö képzete a nemzeti retorikák mögül is előtűnik, eszerint a nemzeti szellemnek vannak olyan felismerhető manírjai, amelyek szerint elődeink beszélnek belőlünk, „mi pedig csak egy rezonáló doboz vagyunk, amely közvetíti a szavakat" (Velikić 2018, 229).

Az Egy mormota nyara az apa alakzatát elbeszélőként állítja be, a fiúét pedig címzettként. Az elbeszélői én nemcsak a maga számára teremti meg ezt a belsővé írt befogadói tudatot, hanem a külső olvasó számára is folytonos jelenléttel ruházza fel, amikor emlékeztető történeteket kapcsol hozzá, $\mathrm{s}$ 
ellenőrzésképpen folytonosan megszólítja a fiúalakot: „ha még emlékszel”, „emlékszel te erre egyáltalán?”. Így a fiú, poétikai múködési eszközként, egy narratív élményközösség termékének tünik, olykor a szemtanúi hitelesség hordozójának. És mindeközben müfajformáló tényezőnek is, hiszen az interlokúció okán a testamentumtól az intelmeken át, a vallomás múfajáig merülnek fel lehetőségek, menet közben inkább érintőlegesen, mert az elbeszélő által a „milyen kétségbevonhatatlan tanulsága volt az életemnek” (Németh 2016, 15) kérdése müfajkonstituáló érvényességgel nem válaszolható meg kielégítő módon. Ezen túl az idevágó, klasszikus beszédformák mindegyikétől idegenkedik az elbeszélö, a felidézett intelem (Gróf Széchenyi István intelmei Béla fiához) szövegét agyrémnek minösíti, és többnapi gondolkodás után sem igen lel olyan tanulságra, amely klasszikus veretü testamentumként, maximaként funkcionálhatna. A mindvégig nyitott müfaji kérdés pontosabb körvonalazásához a regény zárlatában kibontakozó gyilkosság-narratíva képzetrendszere („Valószínüsíthetö, hogy HV nem követte el a tettet, amiért vezekel. Egy kényszerképzetröl vall”, Sipos 2016) visz majd közelebb, szakítva az intelem müfaji tradíciójának tematikus kereteivel, inkább a vallomás, a gyónás felé terelve az értelmezést. Az elbeszélő a konfesszió egyedül lehetséges címzettjeként jelöli meg a fiú személyében azonosítható te-t: „és csak neked fogom elmesélni ezt az egészet" (Németh 2016, 204).

Olyan szöveghely is van, amely elbizonytalanítja a fiú lehetséges olvasói mivoltát, beszédbeli létrehívását puszta ürügyként, mintegy retorikai-pszichikai segédeszközként állítja be: „ráadásul azt találtam ki, hogy neked írok, tulajdonképpen függetlenül attól, elolvasod-e majd egyáltalán, neked szerkesztettem össze ezt itt, ürügynek használom a létezésed, hogy írás közben ne tartsam örültnek magam" (Németh 2016, 16). Olykor a beszéd alanya mintha átmenetileg meg is feledkezne a narratee lézetéséről. Egyszerüen kikapcsolja az explicit működésrendből, eltávolodik tőle, a saját külső-belső kronotopikus zónáit más módokon tágítja. Idöközönként azonban ,a további részletekkel nem untatnálak”, vagy az ,úgy képzeld el, például, mintha mennél budapesten, a bem rakparon, és mondjuk a batthyány téren..." (Németh 2016,38) típusú beszédmozzanatok figyelmeztetnek a jellemző attitüdre, amely olykor egészen közel kerülhetne az önmegszólításhoz, de időről időre a narratee-hoz családi vonalon kötődő figurák jelennek meg a beszédfolyamban, például: „az anyámmal tehát a nagymamáddal", és a beszéd egyértelmüen visszazökken az interlokúciós szférába. Azért, hogy oldódjon az elbeszélő létmagánya, hogy erösödhessen emlékeinek szituációs kötöttsége, hogy megélhesse a történések megosztásának tapasztalatát, s hogy ily módon értelmét lelhesse az írásnak, és hogy valódi értelmet 
adhasson minden személyes dimenziónak, amely idegenség-történésként válhat elbeszélhetővé. És a többi között azért is, hogy viszonylataiban szituálódjon az elbeszélő, hogy apaként megalkotva önmagát, felelős gondolkodási pozícióba helyeződjön. Nem kétséges, hogy ezek a visszazökkenések a múlt idejü valóság szórványos fragmentumainak a felvillantására is alkalmasak, amelyek viszonylatában sajátos színezetet nyer az áldozatiság, majd a tettesség személyes tapasztalata. A hozzá beszélés relációjában kerül a történetbe a helyszínvadász egy magánéleti keresési élménye és a rátalálás társas öröme:

mire anyáddal megtaláltuk a házat, ahová azután születtél, vagy százat megnéztünk már, és mindről az első pillanatban tudtuk, hogy reménytelen, itt viszont, már ahogy az öreg haidekker-kapu mögött a kerti úton föltünt a két toprongyos puli, boldog remegés fogott el, és később, amikor az első tíz méter után, a két útra hajló aranyesőbokor ágai között visszanéztem anyádra, a szemében láttam, ugyanazt gondolja, amit én, megtaláltuk, amit kerestünk... (Németh 2016, 36).

Azt is a tudomásunkra hozza az elbeszélö, hogy a családtörténetnek itt háttérben hagyott mellékszálai is vannak, így érintőlegesen meglehetősen széles összefüggésrendszer rajzolódik ki, akár váratlan, esetleg nehezen érthető kapcsolódásokkal is, mert ,pont ezt nehéz szétszálazni, hogyan függenek össze a dolgok, és egyáltalán mikor és mivel kezdődik el a történet..." (Németh 2016, 39). A két regénykoncepciót, Németh Gáborét és Dragan Velikićét, az azonos típusú érzékenységek mellett az is egymás közelében tartja, hogy mindkettő fikció létesítéséhez keres valós helyszíneket, miközben elbeszélőik állandó tartózkodási helye az ideiglenesség. Az „eleve adott” játékba hozása azért lényeges, mert mint a nyelv tropológiájának problematikusságából, illetőleg az írásra vonatkozó kritikai elgondolásokból kikövetkeztethető, csak azt lehetséges megnevezni, ami már megvan. Az Egy mormota nyarában a helyszínvadászi pozíció (az elbeszélő egy Byron-film forgatásához keres tengerparti helyszíneket) a folytonos térváltás indoka. Így az elbeszélés nem köti, nem kötheti meg a territoriális jelentéseket, állandó mozgásban van, mindenütt az interpretáció szabad terét keresve, a nyitások létesítési módjait, de mindenütt a nyugati modernitás szempontjából idegen vonatkozásokba ütközve. „Hangsúlyosan a privilegizált (közép-)európai ember pozíciójából líródó regény a megvetett vagy félelmetes idegenséggel szembeni beállítódások és reakciók megértésére tesz kísérletet" (Csuka 2016). Ezek az alapmozzanatok azok, amelyek majd iróniába fordítják a tanítási hozzáállást: ,»ezek szerint«, mondta a hang a fejemben, »egy apának valószínüleg nem a halkés helyes használatára, az ikes és 
iktelen ragozás közti halálfontos különbségre vagy a pörgetett fonák lebukó átemelésére, hanem utcai harcra kellene tanítania a fiát, már ha képes egyáltalán még bárminek a megtanítására«" (Németh 2016, 63). Jellemzőnek tünik, hogy mindkét regény lezáratlan struktúrák által szembesül a gyengeségekkel, a tévedésekkel, az illúziókkal. Mindkét regény a szerkezetek jól megtervezett nyitva tartásával találja megidézhetőnek a „kor lélegzetvételét”, mindazt, aminek az elgondolása is kényelmetlen, ,mindazt, ami az egész élet során a legrestelltebb szégyen volt” (Velikić 2018, 171). A Németh-regény zárlata A nyomolvasó egy mondatának szellemi-formai nyitottságait idézi fel az értelmezőben: „A történet nyitva marad. Hozzátoldani, aminek az elgondolása is kényelmetlen, nemhogy a megnevezése. Csak egy utalás, homályos jelzés. Az útirányok látszatra szabadok, valójában pedig minden ajtó zárva. Soha semmi nincs világosan kimondva" (Velikić 2018, 44).

Az evidenciákhoz való viszony tekintetében nem hagyhatjuk figyelmen kívül a szövegben megjelenő elbeszélő alakzatát, ,aki tényleg nem bíbelődött azzal, hogy a fikciót összefésülje a tényekkel" (Németh 2016, 28), miközben pedig könnyedén alkalmazkodhatott volna a tárgyát képező életrajz részleteihez, amelyek teljes egészében megfeleltek a müfaji követelményeknek. Az íróból lett helyszínvadász voltaképpen egy olyan forgatókönyvhöz keres távoli helyszíneket, amely a helyek tekintetében nem törekszik az egzakt meghatározásra, nem határolja be ilyen módon a saját lehetöségeit, nem nagyon törödik a tényekkel, amelyekkel pedig ,éppen lehetett volna kezdeni valamit” (Németh 2016, 29). Velikić író-elbeszélőjét egészen hasonló gondolkodásából az anyafigura (,az anya az elbeszélő antipólusa”, Živanović 2015, 190) erőteljes ellenérzései mozdítják ki: „Úgyis mindent úgy fogsz majd kiagyalni. Nem érdekelnek a kitalációk" (Velikić 2018, 44). Itt emlékeztetnék Németh Gábor egy interjúbeli (Keresés mint szenvedély) kijelentésére: „Nem kitalálni, hanem leírni szerettem volna, úgy, ahogy én láttam ezeket, persze minden leírás elképzelés." Semmit se kitalálni, csupán rátalálni a dolgokra, fellelni azokat a történeti vagy a biografikus múlt emlékezeti palettáján, ami igazán a tied, sugallja az anya, az az, ami az emlékezetben él: az emlékezet a létezés biztosítéka. „A múlt soha nincs befejezve, folyamatosan kipótlódik” (Velikić 2018,235). A nyomolvasó figurái között van olyan, akit egyenesen az emlékezés tart életben, aki mások emlékezetét a saját emlékezetének a kitágításaként értelmezi, a különböző személyi bonyodalmak ellenére is. Az élet konfúziói voltaképpen a temetői helyszíneken tisztulnak le renddé. Fontos mozzanatnak számít a történetek befejezhetetlenségének belátása: a sírhalmok alatt mindenütt „félbetört mesék”, „megszakított történetek” nyugszanak. 
Az Egy mormota nyara térértésének földrajzi széthelyezése, a helyszínkeresés fikciója és az otthoni létterekhez való folytonos emlékezeti visszatérés hívja elő a jellemzővé erősödő politopikus tapasztalatot. Egy olyan politopikus tapasztalatot, amelyet majd a sokszínüen vibráló idegenségélmények jellemeznek közelebbről: a narratív ritmus ily módon a változó téreffektusok függvénye. „A főhős utazásainak az esetlegessége és sok helyszínt érintő volta meghatározza az elbeszélésének a lineáris, fragmentált formáját is. Újabb és újabb elágazásaiban újabb és újabb témák, emlékképek, történetek, elmélkedések kerülnek elő" (Takács 2016, 958). Velikić ezeket a jelentéseket Gombrowicz naplójából idézve (merthogy ez a regény is intertextusok, betétek és digressziók hálózatában müködik) explikálja, a múlt által behozott eseményeknek a kaotikusságára, az esetlegességére és fragmentarikusságára utalva. Mindkét regény a saját életbe szóló utazás vonalait rajzolja, így mindkét regény gyermekkori emlékezeti szintjein és későbbi terepein is müködnek a tapasztalati távolságok változatai, a „végtelen távolságok”, az „őjítően kezelhetetlen távolságok”, a „félelmetes idegenségek", a szorongás irracionális és feldolgozhatatlan hatásjátékai. Mindeközben jól érzékelhető, hogy mindkét szerzőt mélyen érdekli, hogyan lehet hasznosítani az időbeli, az emberközi, a kulturális távolságok produktivitását. Az Egy mormota nyarában a szövegeket alakító erök a távoli történetek idegenjét a saját társadalmon belüli idegenségek emlékezeti vonatkozásaival párhuzamosan mutatják fel. Elemi távolságunkat a más bőrszínü, etnikumúvallású idegenekhez azzal is jelzi a szöveg, hogy egy ízben feltevésként közli, valószínűleg automatikusan fehér embereket képzel az olvasójuk az általa előadott történetek mögé, holott mindenütt négerekről van szó.

Az első idegenségtapasztalatok itt is gyermekkori élményként merülnek fel: „annyira nem volt egyébként errefelé igazi néger, annyira nem jutott szegény magyaroknak, hogyha egyszer mégis idekeveredett egy véletlenül, te meg mondjuk nem voltál több négyévesnél, és voltál annyira bátor, hogy hozzáérjél, hát utána megnyaltad az ujjad, biztos-e, hogy nem volt a bácsi csokiból" (Németh 2016, 46-47). Amikor cigány figurák megidézésével építi fel a regény az idegenül ható jelentéseket, rendkívül érzékletes az az elöítéletekből konstruálódó történet, amelyben az elbeszélő arra döbben rá, hogy ő is idegenként realizálódik mások számára. Tapasztalati útjait feltérképezve, saját egykori áldozati helyzetét is felidézve építi ki magában a gyilkossá válás képzetrendszerét, hogy ebben a dimenzióban is megmutathassa az idegen iránti ellenszenv múködésrendjét, lehetséges szituációs következményeit. Az Egy mormota nyara, amely „,akárcsak Camus vagy Mészöly, metafizikai szintre emeli a rejtélyt, s vele a szöveget behálózó - mindannyiunk számára ismerős, mert Európát szinte a Közöny első 
megjelenése idejéhez (1942) hasonló intenzitással átjáró - szorongást" (Simon 2016) legfontosabb jelentéstávlatai számomra Dragan Velikić A nyomolvasó címü anyaregényének értelmezési kontextusában, prózapoétikai párhuzamaiban, „kérlelhetetlen dramaturgiájában” bontakoztak ki a maguk teljességében. Vonatkozások, utalások, összefüggések világítják meg, hogy az idegenségeket, félelmi mozzanatokat, feszültségeket, nyugtalanságokat megérzékítő mindkét regény az interlokúciós szemléletủ elbeszélői attitüdökből építi ki a maga szerkezetét, azzal, hogy A nyomolvasóban az interlokúciós és delokúciós gondolkodás sajátos együttmüködése is jelenléttel bír. A pontosítás kedvéért kell hozzáfüzni, hogy az Egy mormota nyarában a „róla való beszéd” inkább a hozzábeszélés keretei között jelenik meg, és itt is szinte csak nyomokban.

Dragan Velikić széthelyezi a közös családi múltat a volt Jugoszlávia városaiba, tengerparti hotelekbe, felidézve a közös visszaemlékezési helyzeteket, sőt az anyai korrekciókat is a múlt történéseit illetően. Az anya emlékezetében, akit leginkább a köztes terek, a köztes idők és az idegen életek maradékai kötnek le, és aki szinte a saját történeteinek a metaforájává öregszik, elképzelhetetlenül sok életsors raktározódott el, banális részletek tömkelege. Az elbeszélő egyik különös tapasztalata az, hogy milyen nagy a távolság az ellenőrzött élettörténetek és az anya által előadott pontatlan változatok között. „Az anyáról szóló narráció megteremti az önelbeszélés azon tereit, amelyekben mindent meg lehet kérdőjelezni, minden felülvizsgálható, újraértelmezhető és újraértékelhető" (Živanović 2015, 190). Az író-narrátor nem tud megszabadulni a jugoszláviai vasúti utazások hagyatékától, látásmódját szinte béklyóba veri a múlt: „Még mindig az a vasút visz, a realizmus kötelékében vergődve; hiába próbálok leszállni róla, pontot tenni, új sort kezdeni, új fejezetet nyitni" (Velikić 2018, 165). Az elbeszélö tervei között szerepel egy hotel-regény megírása is, így iktatja be a szállodajel által hordozott jelentéslehetőségeket (a szálloda mint ,a kivárás és a megihletődés terepe, a dupla fenekü fantáziák birodalma”, Velikić 2018,74) a regény gondolatmenetébe, amely jel az Egy mormota nyara olvasója számára is meglehetösen aktívnak bizonyul. Azon érzéseire is hivatkozik, melyek szerint akkor is sok volt a láthatatlan határ, a külföldszerüség, az idegenség ezeken a hazai vasútvonalakon, amikor az ország lakói, függetlenül attól, hogy mely városban éltek, még azt hitték, hogy egységes területen utaznak, amikor még nem sejtették, hogy itt hamarosan megint külföld lesz, amikor még nem különböztek a zászlók, a himnuszok és az egyenruhák. Rokon vonásként, Velikić elbeszélöje az Egy mormota nyara címủ regényben is tapasztalható hálózatos térszerkezetet hoz létre, de kevésbé eltávolodva korábbi életének tereitől. Ez a regényíró-elbeszélő is helyszíneket keres, az egykori Jugoszlávia, a családtörté- 
neti múlt mitikus helyein, egy következő regényének a terrénumait (egyébként mindkét narráció hátterében meghatározó módon múködik az éppen keletkezőfélben lévő regény). A pályájának nyomvonalát szeretné kijelölni, ahogyan mondja, traszírozni. Még tágítja is e nyomvonalat, hiszen ismerősökkel, barátokkal is rituális emlékezeti utakra küldi az elbeszélő gyermekkori énjét. Egy ízben megjegyzi, hogy a saját élet fikcionalizálásában nem a kitalálásra, hanem a megtalálásra törekszik, másutt pedig azt hangsúlyozza, hogy semmit sem fog kiagyalni, csakis felkutatni, a realitás talaján maradva. „A fantasztikum kirántja alólam a talajt. A mesék mindig viszolyogtatnak. Örületbe kerget minden olyan eseménysor, amelyre nincs racionális magyarázat" (Velikić 2018,21). Amikor az elbeszélő elhagyja a várost, amelyben a gyermekkorát töltötte, a proporcionális élményeit, a viszonylati vonatkozásokat magával viszi. Érzései szerint a távozások tulajdonképpen mindig véglegesek, tényleges visszatérés nincs, hiszen az egykori otthonos viszonylati rend nem állítható vissza többé. Az Egy mormota nyara térelképzelései rávetíthetők A nyomolvasó címü regény kronotopikus müködésmódjára: ,,azóta tudom, hogy nem történhet meg bármi bárhol, hogy a látható terekhez láthatatlan események tartoznak, láthatatlanok, mert nem a jelenben vannak, hanem a »már nem«-ben vagy a »még nem«-ben, hogy bizonyos terek csak azért léteznek, hogy egyszer majd megtörténjen bennük és általuk valami, valami jó vagy éppen jóvátehetetlen" (Németh 2016, 69).

Velikić regénye is müködteti a címzett alakzatát, az előző regény családi mintáihoz viszonyítva azonban mintegy fordított relációban: az elbeszélöt ugyanis fiúi minőségében alkotja meg. A különbség a Németh-regényhez képest abban áll, hogy a halott anyához való beszédben a ténylegesen már nem megszólítható megszólítása jelenik meg prózai szervezőerőként. Amikor ez a sajátos beszédszituációt kialakító elbeszélés a halálba helyezi az anyát, mintegy kimozdítja a megszólíthatósági zónából, egy hiánytapasztalat fájdalmaiból építkezik. Az elbeszélő az anya elveinek megfelelve igyekszik fogalmazni, és végül egy levélformájú szöveggel zárul a „hozzá való beszéd”, amely a közös időkre apellál. Ezzel a megszólítással a már idősödő elbeszélő az anya iránti tartozásait igyekszik leróni, egy gyermekkori emlék nyomán arról beszélve, hogy azóta a strand (érdemes megfigyelni, hogyan építi be a Németh-regény a strandnarratívák idegenségmozzanatait) egykor közösen tapasztalt primitív emberei elözönlötték a világot, és csak az emlékezés által szállhat szembe velük: „Mindenütt ott vannak már. A repülőtereken és a sétahajókon, a bankokban és a parlamentekben. Befészkeltek a minisztériumokba, az akadémiákra, egyetemekre, a kórházakba, a filmstúdiókba, színházakba. A világ torz alakok birtoka lett. [...] Ez már nem az a város, amelyben megszülettem. [...] Mert 
végül mindig a barbárok jönnek el" (Velikić 2018, 252-253). A jugoszláv térségben végbemenő változások nyomán érvényesülő hatalompolitikai koncepciók fejleményeit listázzák a mondatok. Van ebben a poszthelyzetủ megszólítási eseményben, ebben az utólagos hozzá való beszédben valami egészen drámai, a megszólítás jelene, a szöveg így létrejövő mostja szinte élőként tételezi a megszólítottat. Minthogy azonban az elbeszélő a halott anya (aki mind jelenvalóbb a bensőjében) fiaként hozza létre magát, a megszólítás már nem hívja be a tanúságnak a visszaigazolás lehetőségét is tartalmazó alakzatait, amelyeket az Egy mormota nyarában megtapasztalhattunk. Az igaz beszéd garanciáját azonban a halott anya alakjának a tisztelete is megadhatja. A regények összevetése során nem lehet eltekinteni attól a problémától, hogy a müfaji komponensek között hogyan, milyen eszközökkel jelenik meg a konfesszionális hangnem, a gyónás, a feltárulkozás mozzanata. A feltárulkozáshoz kapcsolódó jelentésvonatkozások már A nyomolvasó élén álló, Borislav Pekićtől származó mottóban jelen vannak: „Feltárulkozás után semmivel sem érzi tisztábbnak magát az ember, mint amilyen addig volt. Ellenkezőleg. Szemétgyüjtő ládának érzi magát. Minthogy jobbik énjeit minden néven nevezhető változatban kiöntötte magából, a legrosszabbikkal maradt magára, azzal, amelyiket soha senkinek nem tár fel".

A nyomolvasó elbeszélője maga is „fél lábbal kimozdulóban” ebből a világból, folytonosan mozgásban, egy szilárd pont után kutatva él, ahol fellélegezhetne, ahonnan beláthatná a hibáit, és ahonnan elindulhatna a megfelelö irányba. Végül önmagában fedezi fel azt az elidegeníthetetlen területet, amelyre nem érvényesek az útlevelek. A helyszínkeresés fikciója, a helyek természetének foglyul ejtése ebben a regényben is erősen befolyásolja a térszervezési tendenciákat: egy majdani regény helyszíneit keresi az író, voltaképpen egy anyaregény múltbeli valós helyszíneit. Így a jelen regény narratív alkotóelemeiként a nyomfeltárást segítő helységek jelentései, a lokális szubjektumok történetei, a levegö kémiai összetételének emlékei, a korok szagjellemzői jelennek meg. Az író-elbeszélő ismerteti majdani formakoncepcióját, amelyben az általunk éppen olvasott regény felépítési sajátosságaira ismerünk. „Mi más a regény, mint kísérlet, hogy a mindennapok néhány képét ok-okozati összefüggésbe helyezzük, hogy kibontsuk a történetet, mely létezik, mint ahogy ott van a szobor a megmunkálatlan kődarabban. Mindenki láthatatlan könyvtárat, meg nem írt regények kórusát hordozza magában" (Velikić 2018, 145). Az is kimondásra kerül, hogy ez a narratív gondolkodás a hagyományos normákat negligálja: a bonyodalom kidolgozása nem kötelező, a csattanó is elhagyható a zárlatból, a tragikus éppen az, hogy meglepetésre nem számíthatunk, hogy alapvető 
változások sohasem történnek. A nyomolvasóban a „szabad prózának” arra az alineáris, fragmentált, , ,asszociatív, szerkezettelen, motivikusan, ám nem rendszerszerủen összefüggő" (Takács 2016,958) elgondolására is rátalálunk, amelyet Németh Gábor Egy mormota nyara címü regényének alapjellemzőjeként írt le a kritika. Velikić elképzelése bizonyos elemeiben emlékeztet Németh Gábor elbeszéléstechnikájára: „Félretette a linearitást, több kiindulópontból kezdte. Először ír ilyen módon. Mindegyik szereplőnek külön fájlt nyitott. Valahol majd kereszteződnek az útjaik” (Velikić 2018, 210), vagy: „Megfogadtam magamnak, hogy ha úgy tartja kedvem, bármelyik percben rácsaphatom a fejezetre az ajtót" (Velikić 2018, 36) - tájékoztatnak a Velikić-regény önreflexív megjegyzései. Egy későbbi szöveghelyen pedig ezt olvassuk: „Új fájlt fog nyitni, minden szereplőt egy helyre gyüjt össze" (Velikić 2018, 229). Velikić elbeszélöje is hirtelen vágásokkal dolgozik, de bizonyos vonatkozásokban összekapcsolja a szereplőket, az egymásra rétegzett emlékezeteket, valamiféle narratív müködésrenddé szervezi akár a távoli összefüggéseket is, az újabbnál újabb emlékek kereszteződéseit, a gyermeki világ tágulásának helyeit. Ebben az elbeszélöi perspektívában az élet rejtvényekből, előérzetekből, érzékcsalódásokból szerveződik, és mindazokból a lényegtelen artefaktumokból, történésekből, amelyeket az emlékezetünk megőriz. Fontosak a történetek, de az „élet minden történetnél tágasabb. Nem redukálható meghatározott számú alakra és helyzetre" (Velikić 2018, 210). Fontosak a „meglét tartós dokumentumai”, a családi felejtés evidentált adatai, a kronológiák, de az elbeszélő szerint az írók olyan dolgokat is látnak, amit még az archívumok sem tartalmaznak. A temporális értelmú narratív rekonstrukció nehézségeit a következő mondat jelzi: „Egy korszak lefordíthatatlan fogalomhasználata a legjobb bizonyíték eredetiségére" (Velikić 2018, 36).

Ami a tematikus relációkat illeti, az öröklött földrajz szétbomlásának, a rengeteg megjegyzett, az emlékezetben elraktározott toponímia felidézésének (történetmondás közben a falon függő fényképek közti hely mindig egy helynévvel töltődik ki) az elbeszélésében, az Egy mormota nyarához képest más alapelképzelések mentén kirajzolódva, de szintén az idegenségek különböző változatait látjuk megnyilvánulni, itt a távoli, az etnikai idegenség változatait úgyanúgy, mint az intrakulturális, a saját környezetből előlépő, primitíven agresszív viselkedésminták idegenségét. Azért is tünik nehezen megragadhatónak a régi idők atmoszférája, mert, mint az elbeszélő megállapítja (aktuális olvasati lehetőségeket is generálva), valaha ószeresek, kuruzslók és mindenféle csalók vándoroltak Európában, mára viszont teljesen kivesztek az idegenség e klasszikus figurái, miközben afrikai és ázsiai menekültek szállták meg. Nem lehet tehát kétségünk azt illetően, hogy az egyik legjelentősebb párhuzamosság 
abban áll, hogy ennek a regénynek a változásrelációit is az idegentapasztalati folyamatok és a szorongásélmények szervezik, a félelmek, amelyek beíródnak a „leszármazottak genetikai kódjaiba”, jóllehet némileg más előjelekkel, más következtetésekkel. Időnként úgy tünik, a két szerző művészetében, legalábbis az itt tárgyalt müveikben az a közös, ami ugyanakkor éppen meg is különbözteti öket egymástól. Az Egy mormota nyara

épp azt mutatja meg, hogy a folyamat nagyon gyorsan eljuthat egy olyan pontra, ahol már nem is lehet különválasztani a zsigeri gyülöletet és a hirtelen feltámadó pusztításvágyat: nem világos, hogy az elbeszélő életmódszerúen gyülöli-e már a bevándorlókat, és legszívesebben az összest megölné, de legalábbis visszaküldené Afrikába és Ázsiába, vagy csak a szövegben tételesen megjelenő Camus-regény (Közöny, az új fordításban: Az idegen) hőséhez hasonlóan, látszólag megmagyarázhatatlanul, felindulásból és alkalomszerüen, de persze lelkiismeret-furdalás nélkül öl (Bedecs 2017, 114).

A nyomolvasóban az elbeszéló családjának idegenségélményeit a geográfia egyik napról a másikra való átszerveződése, az ország térszerkezetének átalakulása idézi elö, és a privátszférán keresztül látszik a történelem, idegenek váltják egymást a házakban, rátapadnak az elbeszélő múltjára is, és ,járkálnak, esznek, alszanak, civakodnak, szeretkeznek a lakásokban, amelyekben a közelmúltig valami másik nyelv volt használatban" (Velikić 2018, 49). Ahogyan a szülök öregszenek, úgy zsugorodik az ország, szaporodnak a kiszámíthatatlan mozzanatok. A családok szétszakadnak, sokan elmennek, mások maradnak, és így jönnek létre a személyes életek legképtelenebb kombinációi, térbeli kiterjedései. A regény arra törekszik, hogy a világ átrendeződésével beálló átmenetiséget, az idegenséget mint állandóságot jellemzővé tudja tenni. „Minden történet annyi változatban él, ahány szereplője van, fö- és mellékszereplő, kívülálló, néma tanúja, vagy csak odaadó mesélője, aki ráhangolódva követte előzményeit..." (Velikić 2018,248) - olvassuk. Az anya, aki öregségére mindennapos gyakorlatokkal edzve az emlékfelidéző képességét valamiféle memoriális gépezetté válik, és mindinkább csak a részletekkel foglalkozik, szinte elmerül az efemer jelentésekben. Csak az egyre romló elméjére számíthat, hiszen 1958-ban, egy vasúti rablás alkalmával Vinkovcinál eltünik a családi archívum, az a kézzel írt füzet is, amely életének partitúrájaként határozza meg az emlékezetét. Ezután már folytonosan retteg a költözésektöl (,,a költözés belépés egy ismeretlen területre", Velikić 2018,52), fél az áthelyeződésekkel elveszíteni a saját kis univerzumát, amelynek szabályait ő maga határozhatta meg. Amikor szellemi 
leépülése már visszafordíthatatlan, összefüggéstelen beszédéből az derül ki, hogy még ebben az állapotában is idegenül bolyong élete fontos helyszínei és nyelvei között, szállodák nevét suttogja, az egyik városból a másikba helyezi át magát, egyik nyelvi valóságból a másikba („Apa tengereken és óceánokon hajózott, anya az életén", Velikić 2018,46), egyszer a horvát nyelv ijekáv változatát beszéli, majd hirtelen fiumei dialektusban szólal meg. A regény elbeszélője a dialektusváltás sajátos szimbolikájában találja meg azt a vonatkozást, amellyel jelezheti, hogy lassan eléri azt a szellemi állapotot, amelyet megérve az anya már csak a saját emléktereiben élt: „Drága anyám, hamarosan fiumanul fogok megszólalni” (Velikić 2018, 253) - áll a regény zárlatában.

\section{Irodalom}

Bedecs László. 2017. Arab vagy?: Németh Gábor egy mormota nyara. Alföld (8): 111-118.

Csuka Botond. 2016. Demarkációs övezetek: Németh Gábor egy mormota nyara. https:// revizoronline.com/hu/cikk/6246/nemeth-gabor-egy-mormota-nyara. (2016. szept. 5.)

Németh Gábor. 2016. Egy mormota nyara. Budapest: Pesti Kalligram.

Sipos Balázs. 2016. Kétféle téboly: Németh Gábor egy mormota nyara. https:// magyarnarancs.hu/konyv/ketfele-teboly-100103\#. (2016. júl. 14.)

Takács József. 2016. Elmaradt intelmek: Németh Gábor: Egy mormota nyara. Jelenkor (9): 957-960.

Velikić, Dragan. 2015. Islednik. Beograd: Laguna.

Velikić, Dragan. 2018. A nyomolvasó. Ford. Bognár Antal. Budapest: Geopen Könyvkiadó.

Veress Károly. 2009. A távolság hermeneutikai produktivitása. In Veress Károly szerk. A távolság antinómiái, 187-229. Kolozsvár: Egyetemi Mühely Kiadó-Bolyai Társaság.

Živanović, Branislav. 2015. Teret intimnog prtljaga: Dragan Velikić: Islednik. Polja (1-2): 189-194.

\section{PRODUCTIVE DISTANCES - NARRATIVE COMMUNICATION MODELS}

Gábor Németh: The Summer of a Marmot - Dragan Velikić: Investigator

The paper is interested in narrative conceptions that can evoke aesthetic potentials in the sphere of memory, and primarily raises the question of how figures that relate to speech addressed to someone or speech realized about someone work at all. This happens when fictitious forms of the narrator's self-search and hidden expansions 
of family relations become the subject of the narrative. What are the more striking dimensions of the open structure that appears due to the functioning of random combinations? If we read Gábor Németh's novel The Summer of a Marmot or the work of Dragan Velikić The Investigator... (a novel imbued with elements of searching for locations), then the question arises: what conception of understanding develops the novel in relation to the experience of strangeness, what could it appropriate from the world of anxiety and fear, and how the double process of selection and appropriation works in it?

Keywords: delocutional reality, poetics of strangeness, interlocution, communicative dimension, novel

\section{PRODUKTIVNE RAZDALJINE - NARATIVNI KOMUNIKACIJSKI MODELI}

Németh Gábor: Leto jednog mrmota - Dragan Velikić: Islednik

Fokus radu su narativne koncepcije koje mogu da prizivaju estetske potencijale u sferi sećanja. Prevashodno postavlja pitanje kako funkcionišu figure koje se vezuju za govor upućen nekome, ili za govor koji se realizuje o nekome. To se dešava kada fiktivni oblici ,samotraženja“" naratora i skrivena proširenja porodičnih odnosa postaju predmet naracije. Kakve markantnije dimenzije imaju one otvorene strukture koje se pojavljuju usled funkcionisanja slučajnih kombinacija? Kad čitamo roman Gabora Nemeta Leto jednog mrmota ili delo Dragana Velikića Islednik sa elementima traženja lokacija, postavlja se pitanje kakve koncepcije razumevanja nudi današnji roman u odnosu na iskustvo stranosti, šta prisvaja iz sveta strepnje i straha, kako se odigrava dvojni proces selekcije i transformacije.

Ključne reči: delokucijska stvarnost, poetika stranosti, interlokucija, komunikativna dimenzija, roman 